\title{
Economic Journal of Emerging Markets
}

Available at http://journal.uii.ac.id/index.php/jep

\section{Community empowerment in rural infrastructure development program}

\author{
Waridin $^{1 \mathrm{E}^{-}}$, Atika Dzulkhijiana ${ }^{2}$, Izza Mafruhah ${ }^{3 \mathrm{E}^{-*} *}$ \\ ${ }^{1,2}$ Faculty of Economics and Business, Diponegoro University, Semarang, Indonesia \\ ${ }^{3}$ Faculty of Economics and Business, Sebelas Maret University, Surakarta, Indonesia
}

Article Info

Article history:

Received : 20 December 2017

Accepted : 25 January 2018

Published : 6 March 2018

Keywords:

community empowerment, rural infrastruc ture, willingness to pay, CIPOO

JEL Classification:

L9, R58, O21,

DOI: 10.20885/ejem.vol10.iss1.art2

\begin{abstract}
This study evaluates the role of stakeholders in the Rural Infrastructure Development Program (RIDP) and analyzes the intensity of community participation in the program implementation with a willingness to pay. Also, it analyzes the factors that influence community empowerment. This research uses sequential mixed method with descriptive statistics, Context Input-Output and Outcome Process (CIPOO), Analytical Hierarchy Process (AHP) and Willingness to Pay (WTP). The results of the analysis show that the main actors in the community empowerment program are the community followed by the local government, academician, and business actors. The community WTP is IDR 5,100, which helps them to maintain sustainability and maintain projects built by the government actively. The empowerment process is the most important factor followed by context and input as the second priority, while output and outcome become the third priority.
\end{abstract}

\section{Introduction}

Development priorities in Indonesia today are stimulating economic growth and delivering development equally for all Indonesians. The welfare gap is marked one of them with differences in urban and rural poverty. The BPS (2017) report states that the number of poor people in March 2016 was 28.01 million people or 10.86 percent of the total population of Indonesia. BPS found gaps between the proportion of poor people in urban and rural areas. In March 2015, the proportion in rural areas reached $17.94 \%$ while in urban areas the proportion was lower, 10.65\%. The figure declined slightly in March 2016, down to $17.67 \%$ and $10.34 \%$ respectively (https://www.bps.go.id/). High differences in poverty rates occur due to infrastructure development gaps in urban and rural areas.

Infrastructure is currently a major requirement in rural development. The availability of infrastructure both buildings and roads will provide easy access for local economic development. Infrastructure is important to accelerate economic progress and reduce poverty. Infrastructure is public goods and services that enter into the production process as complementary input to traditional production factors such as capital, labor, and entrepreneurship. They help increase return on investment by reducing production costs and improving transition efficiency. Availability of infrastructure and service efficiency determine the success of other production processes. Investments in infrastructure such as energy, water, transportation, and communication technology promote economic growth, reduce poverty, and improve living conditions in developing countries. Infrastructure and economic growth have a fairly complex relationship. The development of infrastructure is important and necessary for industrial take-off and economic growth, but increasing number and more high-tech infrastructure does not guarantee economic growth(De Haan, Romp, \& Sturm, 2007). On the other hand, infrastructure development, especially large-scale infrastructure, has a dilemma because it will have an environmental impact that is a long-term challenge and is feared to affect climate change. The most prominent infrastructure development took place in East Asia, especially China and Vietnam.

Community involvement at the grassroots level from planning to project implementation becomes a necessity. Community-run projects can be managed and maintained better. The community can work with the project developers and handle some aspects of the project and thus develop the capacity of rural communities. The FADAMAis In Nigeria; the term "Fadama" is a Hausa name for irrigable land-usually low-lying plains underlaid by shallow aquifers found along major river systems. The FADAMA is a project initiated by the United Nations and the Government of Nigeria.Is an appropriate step because people are given the authority to select projects that best suit their environment and are supported by various external and internal stake- 
holders (National Fadama Coordination Office Nigeria, 2015). The government remains the motor to rally and mobilize the community, especially in the early stages to create awareness of how community participation will be addressed and achieved. Procedures and mechanisms of community engagement should be undertaken and adhered to so that the government, the business sector, and the community can work in harmony.

Empowerment is a complex issue and can be seen at an individual, organizational or community level and closely linked. At the community and organizational level, empowerment results depend on the level of empowerment of its members. Community empowerment is defined as a process by which people can take power to act effectively to change their lives and environment. The process of community empowerment encourages participation, solves local problems, increases individual and community control, and improves the quality of life and social justice. So far, there has been no consensus on universally accepted methods or measures to evaluate community empowerment processes (Kasmel \& Andersen, 2011). Community empowerment and infrastructure development have a very close relationship, so the Indonesian government applies this pattern in the national development model.

Based on this background, the Government of Indonesia launched the Rural Infrastructure Development Program (RIDP) aimed at creating and improving the quality of community life, both individually and in groups, so that they can solve various problems related to poverty and backwardness in rural areas. RIDPis a community empowerment program based on rural infrastructure development consisting of 1) community empowerment, in which the entire process of activities from preparation, planning, implementation, control, to maintenance involves the active role of the community; 2) alignment to the poor, where the outcomes of both process and utilization activities are endeavored to have a direct impact on the poor; 3) autonomy and decentralization, where local governments and communities are fully responsible for program implementation and infrastructure sustainability; 4) participatory, in which the community is actively involved in every process of activity, and the poor, women and minorities have the opportunity to play an active role; 5) self-reliance; 6) integrated development programs, meaning that programs are integrated with other rural development programs; 7) strengthening of institutional capacity; and 8) gender equality and justice. It is expected that RIDP will accelerate the process of community independence and realize the synergy of various development actors in the context of poverty alleviation in rural areas.

This research was conducted in Semarang Regency, Central Java Province because poverty level in this regency is relatively low $(8,13 \%)$, much lower compared to provincial average which reaches $13,03 \%$. Semarang regency, with 19 districts and 235 villages, became the fifth lowest poverty in Central Java. Banyubiru subdistrict was selected as a research sample because it is located in rural areas, butthe lifestyle of its people has been influenced by urban lifestyle. The population in Banyubiru sub-district is 41,066 inhabitants with 20,611 males and 20,455 females. The education level of the population aged five years and above is an elementary school with $40.98 \%$, junior high school with $18.6 \%$, and senior high school with $16.0 \%$.

This study aims to evaluate the role of stakeholders in the Rural Infrastructure Development Program (RIDP) in Semarang Regency and to analyze the intensity of community participation in RIDPimplementation with a willingness to pay. The study is also to analyze the factors that influence community empowerment.

Structuring of infrastructure, directly and indirectly, will change the rural environment to make it more organized (Laah, Adefila, \& Yusof, 2014). Developing countries have experienced growth in infrastructure development although there are still many deficiencies in the number, quality, and accessibility for the community, especially rural communities. Such shortcomings will affect the competitiveness of slowing performance in the economic, health, and education sectors that would harm the poor in rural areas. Community participation in infrastructure development in the region will create awareness, mobilization, and creative potential including talent, skills, human resources, and finance. The results of research in African countries in 2010 indicate that a sizable infrastructure investment of up to 15\% of GDP is often inefficient due to weak public management. The private sector has contributed significantly to increasing efficiency and access but has not been an alternative to public engagement and financing. Another weakness in inefficient infrastructure development is the absence of monitoring of infrastructure spending and conditions (Marianne Fay \& Toman, 2010). The needs of the people involved in rural infrastructure development through empowerment demonstrate specific implementation shifts. Policies and strategies are directed primarily at nature control, technology considerations, economic structures, and demographic conditions by considering values, customs, social structures and political participation (Khan, 2005).

Research conducted by Fernández-Moral, Vidueira, Díaz-Puente, \& Nicolás (2015) in rural communities in Cuenca, Spain shows that the willingness of community members to become active agents in the empowerment process is an important aspect of community-based development. The Institute of Community 
Development of Cuenca (IDC), which collaborated with various groups for 30 years with a focus on empowering rural community organizations, stated that the main tool in this process is the evaluation of empowerment approaches and the role of critical friends when helping groups to achieve goals and strengthen them. Group work is crucial to gaining the capacity, skills, and attitudes that enable them to become truly independent after the facilitator has left. To achieve this, facilitators should be able to provide transfer knowledge of their capacities, skills, and attitudes to individuals and entire groups. At the beginning of this process, the role of the leader is crucial to ensure the development of the group. Then, as the group continues to grow, members must learn to take over the leader's role, and they must make their own decisions. At this time, the facilitator becomes a group guide. Finally, when the facilitator has left, the group must be completely autonomous, and members should be able to apply all the capacities built during this process (Fernández-Moral et al., 2015).

\section{Research Method}

Factors affecting the level of community empowerment are analyzed by Context, Input, Process, Output, and Outcome (CIPOO). Context includes aspects of the institution, management systems, organizational performance, and material mastery; input includes internal and external aspects; process consists of approaches to capacity building, new public management, performance, and substantial such as knowledge, attitude, and practice; Output; and Outcome (Mačiulskyt , 2014).This research uses the sequential mixed method with descriptive statistics, Context Input-Output and Outcome Process (CIPOO), Analytical Hierarchy Process (AHP) and Willingness to Pay (WTP) (Saaty, 2008).

Stages in the contingent valuation method (CVM) analysis in this study are a) Creating Hypothetical Market to formulate a reason why people need to pay for an environmental goods or service; $b$ ) Respondents receive an offer of WTP value (Obtaining bids) with Bidding Game, Closed-ended Referendum, Payment Card, and Open-ended Question.The technique used in this research is Bidding Game because this research wants to know the degree of public participation in contributing to PPIP success seen from the lowest WTP value.

This study used 125 respondents and ten key informants. Respondents will be interviewed with a structured questionnaire for quantitative analysis. Key informants will be interviewed in depth to obtain inputs in qualitative analysis. Respondents were chosen by an accidental method, while key informants were the main figures in the PPIP implementation.

\section{Results and Discussion}

The first objective of this research is to evaluate the role of stakeholders in PPIP activities. Stakeholders consist of four actors: academicians, government, business, and community, while the stages of activities are divided into planning, organization, implementation, and control. Evaluation value ranges from 1 to 10 that are classified as very poor, poor, adequate, good and very good. Respondents were asked to provide an assessment of the performance of each stakeholder. The results show that on average the community earns the highest score of 7.71 for all stages of activity, followed by the government with an average value of 6.30 or adequate. The third role is academicians with a value of 6.10 , while the business has the lowest value in the implementation of this PPIP, which is 4.48 or poor. The Table 1 shows that communities have an important role in infrastructure development. In other words, they are willing to contribute with energy and financial resources.

Table 1. Evaluation of Stakeholder Roles In PPIP activities ( $\mathrm{n}=125)$

\begin{tabular}{cccccccc}
\hline \multirow{2}{*}{ No. } & \multirow{2}{*}{ Activities } & \multicolumn{5}{c}{ Stakeholders Roles } \\
\cline { 3 - 6 } & & Academician & Government & Business & Community & Average & Classification \\
\hline 1. & Planning & 6,50 & 6,50 & 5,50 & 7,89 & 6,60 & Adequate \\
2. & Organization & 6,25 & 6,45 & 5,00 & 7,71 & 6,35 & Adequate \\
3. & Implementation & 6,35 & 6,25 & 4,35 & 7,75 & 6,18 & Adequate \\
4. & Control & 5,30 & 6,00 & 4,50 & 7,50 & 5,83 & Adequate \\
& Average & 6,10 & 6,30 & 4,48 & 7,71 & & \\
& Classification & Adequate & Adequate & Poor & Good & & \\
\hline
\end{tabular}

The second objective of this study was to calculate the value of financial resources that the community would be willing and able to pay with a willingness to pay (WTP). The method used to calculate WTP is the contingent valuation method (CVM). Valid WTP estimates will be used to develop an optimal pricing strategy. 
CVM also can estimate non-user value (Amirnejad \& Aminravan, 2013; Breidert, Hahsler, \& Reutterer, 2006). The method used is by involving respondents to determine their willingness to pay for PPIP.

Table2. Distribution of Respondents' WTP values

\begin{tabular}{ccccr}
\hline No. & \multicolumn{1}{c}{ WTP (Rp) } & $\begin{array}{c}\text { Respondents } \\
\text { (people) }\end{array}$ & Percentage (\%) & $\begin{array}{c}\text { WTP x Respondents } \\
\text { Willing to Pay }\end{array}$ \\
\hline 1. & Rp 4.000 & 64 & 51 & Rp 256.000 \\
2. & Rp 6.000 & 15 & 12 & Rp90.000 \\
3. & Rp 10.000 & 28 & 23 & Rp 280.000 \\
4. & Not willing to pay & 18 & 14 & 0 \\
& Total & 125 & 100 & Rp 626.000 \\
\hline
\end{tabular}

The data in table 2 is then calculated using the average value of WTP which is Rp 5.008 rounded to Rp 5,100. The value can be used as a reference of RIDPmaintenance and sustainability pricing in Banyubiru Sub-district of Semarang Regency.

The third purpose of this research is to analyze the factors that influence community empowerment through infrastructure development program. Community empowerment strategies used are community organizing, community-based development, and the provision of community-based services. Macroeconomic and social structure factors may encourage or inhibit grassroots mobilization. This discussion emphasizes the importance of leadership development, strategic planning, and network building (across neighborhoods, cities, and regions) by mobilizing people to solve their common problems. The main obstacle in community organization is the lack of leadership development training and organizational capacity building (Kellly, 2010).

This research uses CIPOO (Context, Input, Process, Output, and Outcome) that will be processed with Analytical Hierarchy Process (AHP).

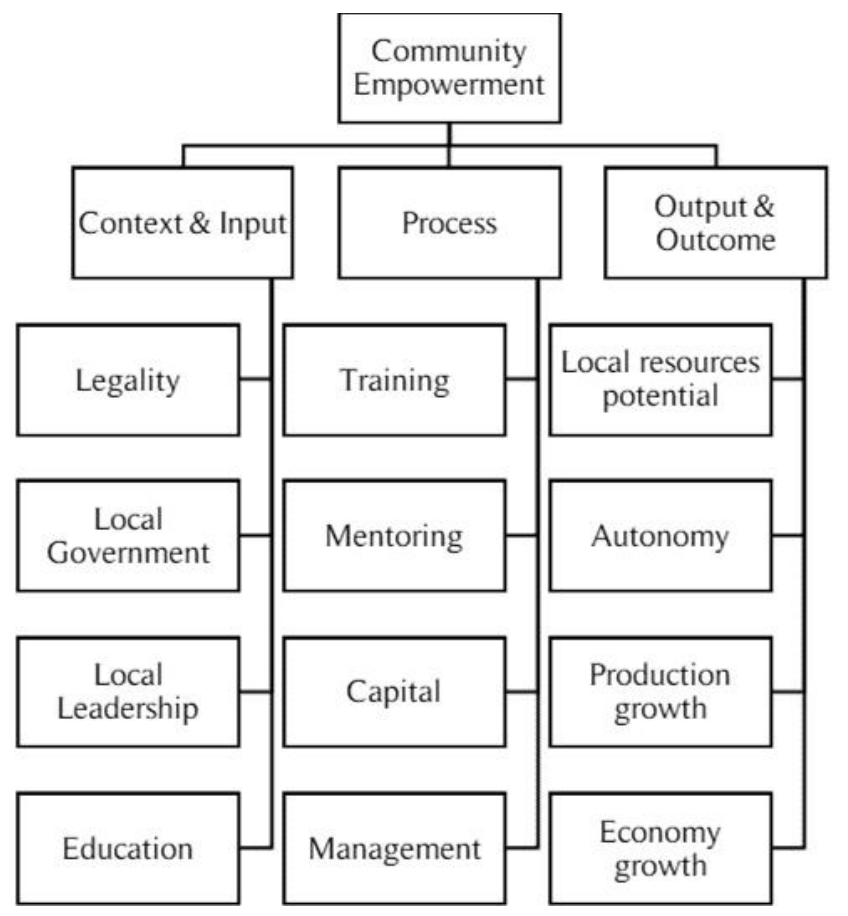

Figure 1. Hierarchy of problems

Figure 1 shows the hierarchy of problems of community empowerment.Empowerment problems are divided into three: context and input, process, and output and outcome. Context and input are divided into four variables: legality, local government, local leadership, and education, while the process is divided into 
training, mentoring, capital, and management. Output and outcome consist of local resource potential, autonomy, production and economy growth. Table 3 shows the results of data processing with AHP in the first step.

Table 3. AHP Results

\begin{tabular}{lcc}
\hline \multicolumn{1}{c}{ Criteria } & Priority Value & Ranking \\
\hline Context \& Input & 0.3458 & 2 \\
Process & 0.3797 & 1 \\
Output \& Outcome & 0.2744 & 3 \\
\hline
\end{tabular}

The results show that process has the greatest effect because the process is the steps undertaken by the community. The second and third priorities are context \& input and output \& outcome.

Table 4. Priority at context and input level

\begin{tabular}{lcc}
\hline \multicolumn{1}{c}{ Criteria } & Priority Value & Ranking \\
\hline Legality & 0.3545 & 1 \\
Local Government & 0.2368 & 3 \\
Local Leadership & 0.2421 & 2 \\
Education & 0.1664 & 4 \\
\hline
\end{tabular}

Table 4 showsthat the results of data processing in the second step of context and input have priority showed in table 4 . The resultshows that legality is a top priority in the development of community empowerment because legality is a form of legal certainty guarantee. The second priority variable is local leadership, followed by the local government. This suggests that in the process of empowerment, people listen more to local leadership than the government. Cultural aspects and local wisdom influence the level of trust in local leadership. The fourth priority is education because society does not regard education as important social capital.

Table 5. Priority at process level

\begin{tabular}{lcc}
\hline \multicolumn{1}{c}{ Criteria } & Priority Value & Ranking \\
\hline Training & 0.3005 & 1 \\
Mentoring & 0.2604 & 2 \\
Capital & 0.2268 & 3 \\
Management & 0.2122 & 4 \\
\hline
\end{tabular}

Table 5 shows that the results of processing at the second level of the process show that training is the priority followed by mentoring. This is because empowerment process requires not only hard skill but also soft skill development followed by structured mentoring. The most prevalent cases in Indonesia show that empowerment programs are not followed by sustainable mentoring, resulting in failure and unsustainable empowerment programs. The third priority is capital because of the understanding in the community that all activities always require capital. The fourth priority is management.

Table 6 lists the results of AHP processing for output and outcome at the second level.

Table 6. Priority at output and outcome level

\begin{tabular}{lcc}
\hline \multicolumn{1}{c}{ Criteria } & Priority Value & Ranking \\
\hline Local resource potential & 0.2668 & 2 \\
Autonomy & 0.2138 & 3 \\
Production Growth & 0.2132 & 4 \\
Economy Growth & 0.3062 & 1 \\
\hline
\end{tabular}


Table 6 shows that the desire for economic improvement is the priority in output and outcome followed by the amount and potential of local resources. Meanwhile, the third priority in output and outcome is the realization of community autonomy or self-reliance as the main actors of empowerment, and the fourth priority is the production increase. The three factors included in the CIPOO are the levers variable in community empowerment based on the RIDPimplementation in Semarang regency. The results of research conducted in Riyom Area, Plateau State of Nigeria, show that community participation is limited to receive information and consultation, therefor that community participation is low. Recommendations includeincreasing levels of awareness and enlightenment about communal participation through mass media, and regular meetings with authorities. The involvement of rural communities in the formulation of projects, planning,and implementation should continue to be encouraged. Governments should create an enabling environment where the grass roots will actively participate in decision-making processes that affect their living conditions, which can stimulate relationships between government and rural communities as partners (Laah et al., 2014). The results of research conducted at Rapla Estonia, in the case of health improvement, show that the role of the community through Organizational Domains of Community Empowerment (ODCE) shows a considerable increase. ODCE was initiated by the community in cooperation with the government as a decision maker. The establishment of ODCE enhances community participation in sustainable health development (Kasmel \& Andersen, 2011).

\section{Conclusion}

The results of the analysis show that the main role in community empowerment process based on PPIP is the community followed by the local government, academicians, and business. Based on this first objective, it is recommended that the government provides greater opportunities for the community to participate in the development, especially RIDP. The second result found that the community WTP is Rp 5,100, meaning that in maintaining the sustainability and maintenance of projects built by the government, the community can actively participate with such WTP value. The third result showed that in empowerment, the process is the most important factor and top priority with training and mentoring as its derived variables. Meanwhile, context \& input become a second priority, and output \& outcome become a third priority. It is recommended that the government always monitors the implementation or the process of community empowerment so that the community will be empowered and self-reliant. This Research will contribute to scholarship, especially institutional theory and regional economic theory based on community participation.

\section{References}

Amirnejad, H., \& Aminravan, M. (2013). The application of the contingent valuation method to estimate the recreational value of Sari Forest. International Journal of Agriculture and Crop Sciences, 5(10), 8-11.

Breidert, C., Hahsler, M., \& Reutterer, T. (2006). A review of methods for measuring willingness-to-pay. Innovative Marketing, 1-32. https://doi.org/10.3111/13696998.2011.644408

De Haan, J., Romp, W., \& Sturm, J. (2007). Public capital and economic growth: key issues for Europe. IMF International Seminar on Strengthening Public Investment and Managing Fiscal Risks from PublicPrivate Partnerships.

Fernández-Moral, M. J., Vidueira, P., Díaz-Puente, J. M., \& Nicolás, V. L. De. (2015). Empowerment evaluation in Spain: The critical friend role in working with rural communities. Procedia - Social and Behavioral Sciences, 191, 984-989. https://doi.org/10.1016/j.sbspro.2015.04.483

Kasmel, A., \& Andersen, P. T. (2011). Measurement of community empowerment in three community programs in Rapla (Estonia). International Journal of Environmental Research and Public Health, 8(3), 799-817. https://doi.org/10.3390/ijerph8030799

Kellly, P. (2010). Poverty in Scotland: Three challenges for community development. Community Empowerment: Critical Perspectives from Scotland. Glasgow.

Khan, Z. (2005). Evaluating the importance of community participation in infrastructure delivery in the Western Cape.Cape Peninsula University of Technology.

Laah, E. D., Adefila, J., \& Yusof, R. (2014). Community participation in sustainable rural infrastructural development in Riyom Area, Plateau State of Nigeria. Journals of Economics and Sustainable 
Development, 5(4), 49-57.

Mačiulskyt, S. (2014). The code of society transformation in social work: Modelling the construction of Lithuanian social work professionalization. Rovaniemi: Acta Universitatis Lapponiensis.

Marianne Fay, \& Toman, M. (2010). Infrastructure and sustainable development. 1. Busan South Korean. https://doi.org/10.1080/15568310601091957

National Fadama Coordination Office Nigeria. (2015). Project Information Document (PID) Appraisal Stage. Abuja. Nigeria.

Saaty, T. L. (2008). Decision making with the analytic hierarchy process. International Journal of Services Sciences, 1(1), 83. https://doi.org/10.1504/IJSSCI.2008.017590 